\title{
Contaminação de poços tubulares em Juazeiro do NORTE-CE
}

\section{Contamination of a well field in Juazeiro do Norte - Ceará}

\section{RAIMUNDA MOREIRA DA FRANCA}

Bióloga. Mestre em Engenharia Civil-Saneamento Ambiental pelo Departamento de Engenharia Hidráulica e Ambiental -UFC, Pesquisadora do CNPq/ PROSAB/ UFC

\section{HORST FRISCHKORN}

Doutor Rer. Nat. em Físico-química pela Universidade de Marburg/Alemanha. Professor adjunto do Departamento de Engenharia Hidráulica e Ambiental da UFC

\section{Manoel Roberval Pimentel Santos}

Mestre.Dutorando em Física pelo Departamento de Física da UFC

\section{LUIZ ALBERTo RIBEIRo MENDONÇA}

Biólogo. Engenheiro Civil pela UFC. Doutor em Recursos Hídricos pelo Departamento de Engenharia Hidráulica e Ambiental da UFC. Professor do Instituto Centec Cariri-CE

\section{MARIA DA CONCEIÇÃO BESERRA}

Bióloga. Especialização em Meio Ambiente pela Universidade Regional do Cariri-URCA

\author{
Recebido: 22/03/05 Aceito: 23/02/06
}

\section{RESUMO}

A interação do riacho dos Macacos e de uma bateria de poços, na sua vizinhança, em Juazeiro do Norte-CE, foi avaliada segundo parâmetros físicos, químicos e bacteriológicos. Foram realizadas também análisés de oxigênio-18 a fim de avaliar a mistura de águas subterrâneas com águas superficiais. Verificou-se que o riacho dos Macacos, na maioria dos parâmetros analisados, não se enquadra em nenhuma das classes de águas doces da Resolução $\mathrm{N}^{\circ} 357$ do CONAMA e da Portaria Nº 518 do Ministério da Saúde. Constatou-se que neste riacho e no lago da Timbaúba a concentração de coliformes totais e termotolerantes é extremamente elevada. Uma simulação computacional do transporte advectivo do contaminante de partículas do rio para o aqüífero com o modelo MODPATH/MOFLOW revela tempos mínimos de transito do manancial superficial poluído até os filtros dos poços entre 15 e 100 dias. Considerando a meia vida dos coliformes em águas subterrâneas de aproximadamente 8 dias e sua alta concentração na água superficial, contaminação dos poços de abastecimento é inevitável.

PALAVRAS-CHAVE: Qualidade de água, contaminação de mananciais, simulação do transporte advectivo.

\begin{abstract}
The interaction of the Macacos Creek and a neighboring well field, in Juazeiro do Norte-Ceará, was assessed through chemical, physicochemical and bacteriological parameters. Oxygen -18 measurements were made for the identification of mixes from surface and underground waters. It was found that Macacos Creek water, with respect to most of the parameters analysed, does not conform to any of the classes for fresh water defined by CONAMA Resolution Nr.357 by the Ministry of Health. In this creek and in the Timbauba Lake the concentration of coliform and thermo-resistant bacteria is extremely high. MODFLOW/MODPATH modeling of advective contaminant transport from the creek to the wells showed minimum transit times between 15 and 100 days. Considering a halflife of about 8 days for coliform bacteria in groundwater and their extremely high concentration in surface waters, contamination of the supply wells is inevitable.
\end{abstract}

KEYWORDS: Water quality aquifer contamination, advective transport simulation.

\section{INTRODUÇÃO}

O município de Juazeiro do Norte situa-se no sul do Estado do Ceará, no Vale do Cariri, sob as coordenadas geográficas $7^{\circ} 12^{\prime} 47^{\prime \prime}$ de latitude sul e $39^{\circ} 18^{\prime} 55^{\prime \prime}$ de longitude oeste, e possui uma área de $235,40 \mathrm{Km}^{2}$. Está inserido na bacia hidrográfica do Salgado e apresenta como principais drenagens o riacho dos Macacos e o rio Salgado. Possui como fonte hídrica direta ou indireta o manancial subterrâneo, que representa a única fonte de abastecimento d'água. É consi- derada a maior cidade do interior cearense em aspecto de desenvolvimento, possui uma população de 212.133 mil habitantes, densidade demográfica de $900 \mathrm{hab} / \mathrm{km}^{2}$, com taxa de urbanização de 95,32\%. Apresenta um comércio bem desenvolvido e festas religiosas que atraem 
romeiros e turistas do Brasil e do exterior em média anual de, aproximadamente, dois milhões de visitantes (IBGE, 2000).

De acordo com Ceará (2003), quase $100 \%$ da população urbana é abastecida basicamente com água proveniente de uma bateria de 18 poços, implantada pela companhia a partir de 1976, com uma produção máxima de $2.592 \mathrm{~m}^{3} / \mathrm{h}$, operada $24 \mathrm{~h} /$ dia. Nove poços da bateria encontram-se nas margens do riacho dos Macacos (Figura 1), que anteriormente drenava a área exudante do aqüífero Rio da Batateira (aquífero superior no Vale do Cariri). Hoje, o fluxo natural deste riacho é substituído por águas de esgotos.

Todos os poços exploram o aqüífero semi-confinado Rio da Batateira, com profundidades entre 80 e $200 \mathrm{~m}$. A estratigrafia geológica de uma seção da bateria de poços e o perfil construtivo do poço PT 03, que é representativo para os demais é mostrado na Figura 2. Uma descrição detalhada da geologia deste aquiífero encontra-se em Mendonça (1996).

Naturalmente, dependendo da permeabilidade do leito do rio e da diferença de carga potenciométrica entre o rio e o aqüífero, a água pode fluir do rio para o aqüífero ou vice-versa. Normalmente, nos aqüíferos aluviais, a recarga tem origem fluvial nos períodos de altas águas, enquanto que o fluxo de base dos rios, nos períodos de baixas águas, é assegurado pelas águas subterrâneas.

Mendonça et al. (2005), utilizando medidas isotópicas de oxigênio-18 e carbono-14 nas águas subterrâneas da região do Cariri, comprovaram que elas são misturas de paleoáguas (idade >10.000 anos), provenientes de um fluxo regional ascendente no vale, com águas pluviais recentes infiltradas diretamente no Vale do Cariri. Tal fato chama atenção com relação à situação atual da superex- plotação das águas subterrâneas, uso e ocupação desordenada da área de recarga das unidades aqüíferas, falta de conservação e proteção nas áreas de influência dos poços e à falta de informaçôes sobre a vulnerabilidade natural dos aqüíferos.

O presente trabalho tem como objetivo avaliar a interação entre unidades aqüíferas e mananciais superficiais poluídos, o grau de poluição e/ou contaminação da bateria de poços tubulares, que abastece o município de Juazeiro do Norte, e do riacho dos Macacos, por meio de análises físicas, químicas, bacteriológicas e isotópicas.

\section{METODOLOGIA}

Com base na localização dos poços utilizados para abastecimento humano, situados em áreas críticas e vulneráveis à poluição, e considerando a presença de mananciais superficiais susceptíveis à poluição localizados em áreas adjacentes aos poços, foram selecionados 12 pontos de coleta, a fim de se obter dados sobre a qualidade da água dos poços e mananciais superficiais. No riacho dos Macacos, a escolha dos pontos de amostragens foi com base nos locais de descarga de poluentes a montante e jusante de parte da bateria de poços localizada na Várzea da Timbaúba (Figura 1). Adotou-se PT para poço tubular e RM para o riacho dos Macacos, com indicação do poço mais próximo em parêntese.

As coletas foram realizadas durante 3 meses (junho, novembro e dezembro de 2002) do período seco e em mais 3 meses (janeiro, abril e maio de 2003) do período chuvoso. Nas coletas de 2003 foram incluídos os poços PT11 e PT12 que exploram o mesmo aqüífero, porém, fora da bateria aqui pesquisada e distante do riacho dos Macacos, para obtenção de parâmetros para o aqüífero não poluído.

\section{Métodos de análises dos parâmetros determinados}

Dureza: método titulométrico do EDTA (APHA, 1995).

Cloreto: método titulométrico do EDTA (APHA, 1995).

Amônia: método da nesslerização direta (APHA, 1995).

Nitrato: método espectrofotométrico do salicilato de sódio, método de Rodier (APHA, 1995).

Demanda Bioquímica de Oxigênio: método dos frascos padrōes (APHA, 1995). Demanda Química de Oxigênio: refluxação fechada do dicromato de potássio (APHA, 1995).

Alcalinidade: método titulométrico e potenciométrico (APHA, 1995).

Oxigênio Dissolvido: determinação in loco, utilizando oxímetro modelo 55 YSI Condutividade Elétrica: determinação in loco, utilizando condutivímetro portátil, (WTW).

$\mathrm{pH}$ : determinação direta in loco com medidor de $\mathrm{pH}$ da Digimed.

$\delta^{18} O$ (Oxigênio 18): espectrometria de massa.

Coliformes Totais e Termotolerantes: método cromogênico.
As análises isotópicas foram feitas pelo Laboratório de Ecologia Isotópica da Universidade de São Paulo-USP, no Centro de Energia Nuclear da AgriculturaCENA em Piracicaba. As medidas de ${ }^{18} \mathrm{O}$ são feitas em relação ao padrão VSMOW (Viena SMOW: Standard Mean Ocean Water), fornecido pela Agência Internacional de Energia Atômica em Viena/Áustria) e expressas em valor de $\mathrm{d} \%$ o (delta nor mil).

$\delta \%_{0}=\left[\frac{\mathrm{R}-\mathrm{R}_{0}}{\mathrm{R}_{0}}\right] \times 10^{3}$,

onde:

$\mathrm{R}$ é a razão isotópica $\left({ }^{18} \mathrm{O} /{ }^{16} \mathrm{O}\right)$ entre o isótopo pesado ${ }^{18} \mathrm{O}$ e o mais abundante ${ }^{16} \mathrm{O}$ na amostra; e $\mathrm{R}_{0}$ : é a razão isotópica $\left({ }^{18} \mathrm{O} /{ }^{16} \mathrm{O}\right)$ do padrão. O erro das medidas é cerca $0,1 \%$.

Na simulação utilizou-se o modelo computacional MODPATH, em conjunto com o MODFLOW, para simular o transporte advectivo de partículas contaminantes da fonte de poluição (riacho) até o filtro dos poços. O MODPATH traça o percurso de partículas por transporte advectivo utilizando as cargas hidráulicas calculadas previamente pelo MODFLOW. Essa simulação completa encontra-se descrita em Santos (2003).

\section{RESULTADOS E DISCUSSOOES}

A qualidade da água é definida em função de valores máximos permitidos para variáveis físicas, químicas e biológicas. A classificação dos corpos d'água é estabelecida a partir da Resolução CONAMA No 357 de 15 de março 2005, que enquadra as águas em nove classes através de condiçōes indispensáveis, visando os diferentes usos e equilíbrio ecológico dos corpos d'água. A água para consumo humano deve-se ajustar a padrōes adequados de potabilidade segundo as normas do Ministério da Saúde e da Organização Mundial de Saúde. A Portaria do Ministério da Saúde No 518, de 25 de março de 2004, estabelece os procedimentos e responsabilidades relativos ao controle e vigilância da qualidade da água para consumo humano, bem como o seu padrão de potabilidade.

\section{Condutividade elétrica - CE}

Durante o período seco (Figura 2) a condutividade elétrica média da bateria de poços estudados variou de $150 \mu \mathrm{S} / \mathrm{cm}$, no PT 17 , a $549 \mu \mathrm{S} / \mathrm{cm}$, no PT $2 \mathrm{~A}$. Durante este periodo as águas dos poços apre- 


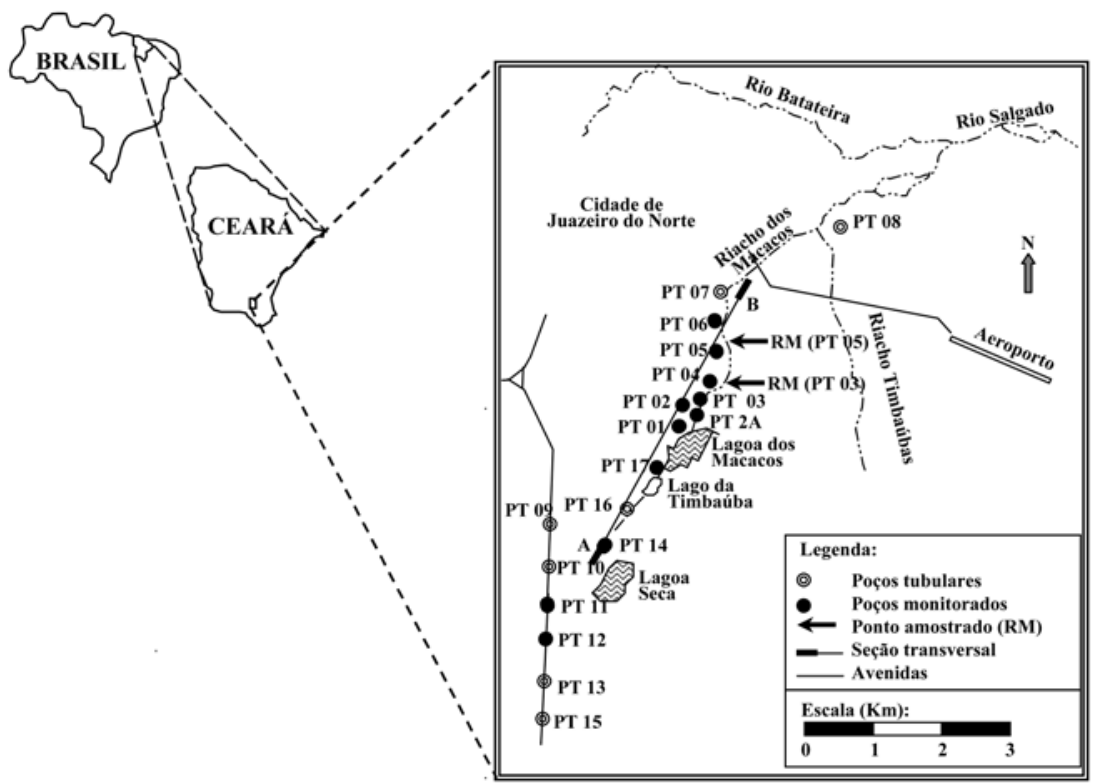

Fonte: Mendonça et al., 2005

Figura I - Bateria de poços e mananciais superficiais na área de estudo

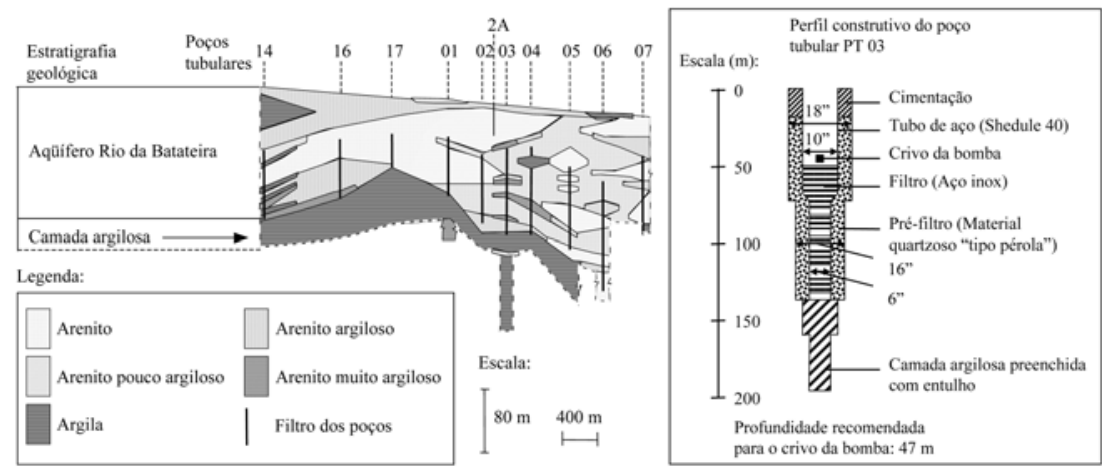

Fonte: Mendonça, 1996

Figura 2 - Estratigrafia geológica da seção AB e perfil construtivo representativo 
sentaram maior carga de íons. Já durante o período chuvoso (figura 3), a CE variou entre $131 i \mathrm{~S} / \mathrm{cm}$, e $506 \mathrm{iS} / \mathrm{cm}$. Ocorreu uma diminuicão dos valores em quase todos os poços, com exceção de PT 03, provavelmente, devido a recarga do aquífero a partir de águas profundas ascendentes.

Durante o período chuvoso (Figura 3), no riacho dos Macacos, a CE diminuiu; o menor valor foi de $358 \mathrm{i} S / \mathrm{cm}$ e o maior, $756 \mathrm{i} S / \mathrm{cm}$. Essa diminuição, certamente, aconteceu devido a diluição com águas provenientes das precipitações ocorridas neste período.

\section{pH}

Na maioria dos corpos d'água naturais, o pH é influenciado pela dissolução do ácido carbônico ou ainda pelo despejo de efluentes domésticos e industriais ou pelo intemperismo de rochas e da erosão de áreas agrícolas com uso de corretivos e fertilizantes (Conte et al, 2001).

A maioria das águas subterrâneas tem pH entre 5,5 e 8,5. Em casos excepcionais pode variar entre 3 e 11 (Santos, 2000). A legislação brasileira estabelece valores de $\mathrm{pH}$ entre 6,5 e 8,5 para águas destinadas ao consumo humano, e entre 6,0 e 9,0 para todas as classes de água doce.

Durante o período seco (Figura 4), as águas dos poços apresentam valores médios máximo de $\mathrm{pH}$ igual a 7,6, no PT 05, e pH médio mínimo de 6,2, no PT 2A. No período chuvoso (Figura 5), o valor médio máximo de $\mathrm{pH}$ 7,4 foi constatado no PT 14 e o mínimo de 6,2, no PT 2A. Na época da perfuração (1976), o PT 04 apresentou pH 8,2 e durante o monitoramento apresentou valor médio de 6,7. No riacho dos Macacos, no ponto vizinho ao PT 05, na coleta de maio 2003, o valor de $\mathrm{pH}$ não condiz com o limite estabelecido para a classe de águas doces. Durante o período seco, o pH médio foi 7,0, no ponto vizinho ao PT 03, e 7,5, no ponto vizinho ao PT 05. No Lago da Timbaúba o valor médio foi 7,4 . Apesar da pequena variação constatada, o pH dessas águas pode variar em função da temperatura, atividade biológica e lançamentos de efluentes.

De acordo com a Resolução No 357 do CONAMA, considerando valores médios, as águas do riacho dos Macacos se enquadram dentro das classes, 1,2,3, ou 4, classificadas como água doce.

\section{Oxigênio dissolvido}

Durante o período seco, o valor de OD nos poços (figura 6) variou de $3,8 \mathrm{mg} / \mathrm{L}$, no PT 17 , a $6,8 \mathrm{mg} / \mathrm{L}$, no PT 11. No período chuvoso (figura 7), o OD na água dos poços se manteve quase estável, não apresentando grandes variaçōes, o menor valor foi de $4,7 \mathrm{mg} / \mathrm{L}$ e o maior, $6,0 \mathrm{mg} / \mathrm{L}$. No riacho dos Macacos (Figura 7), durante o período seco, o menor valor foi $1,1 \mathrm{mg} / \mathrm{L}$, nos dois pontos amostrados; o maior foi $1,8 \mathrm{mg} / \mathrm{L}$, no ponto vizinho ao PT 05. Neste período do ano a carga orgânica lançada no riacho é mais concentrada.

Durante o período chuvoso, o aumento no OD é significativo, partindo de valores próximos de zero até atingir 5,6 $\mathrm{mg} / \mathrm{L}$, o maior valor. Esse aumento é associado à ocorrência de chuvas, cujas águas diluem os esgotos lançados no riacho e aumentam a turbulência de fluxo, propiciando uma maior oxigenação da água.

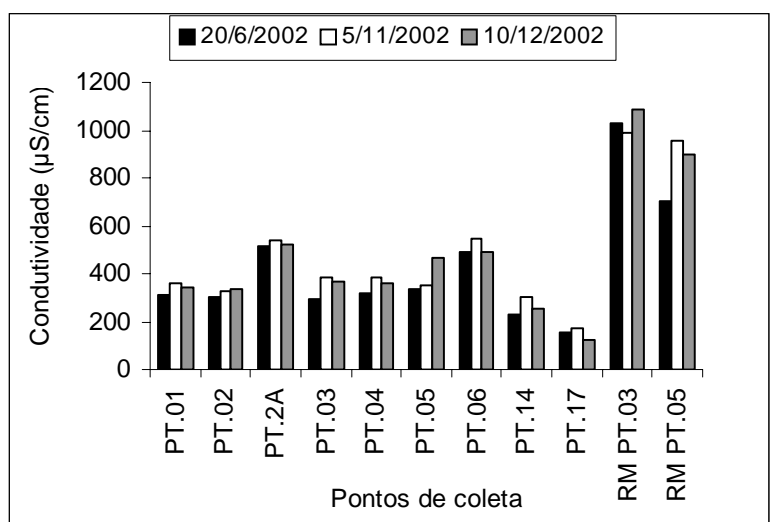

Figura 3 - Condutividade no período seco

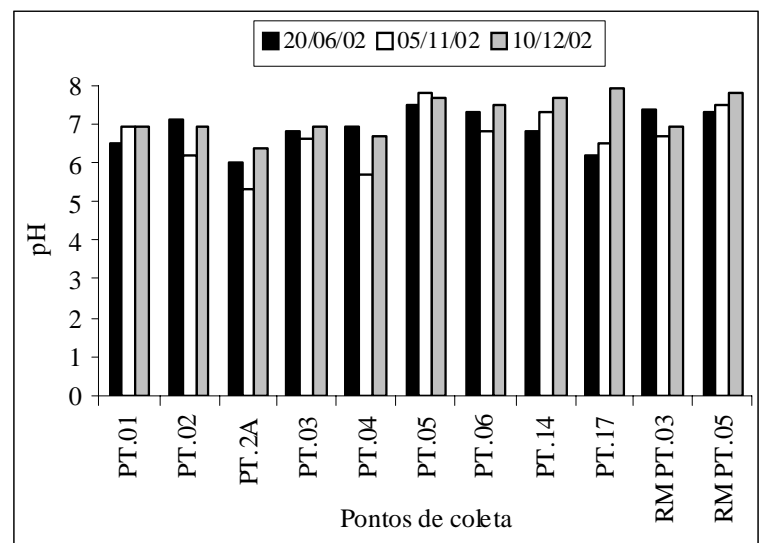

Figura 5 - pH no período seco

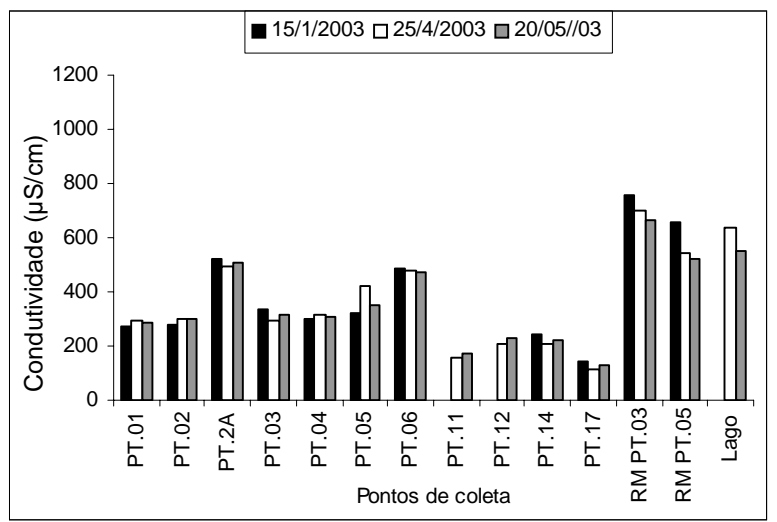

Figura 4 - Condutividade no período chuvoso

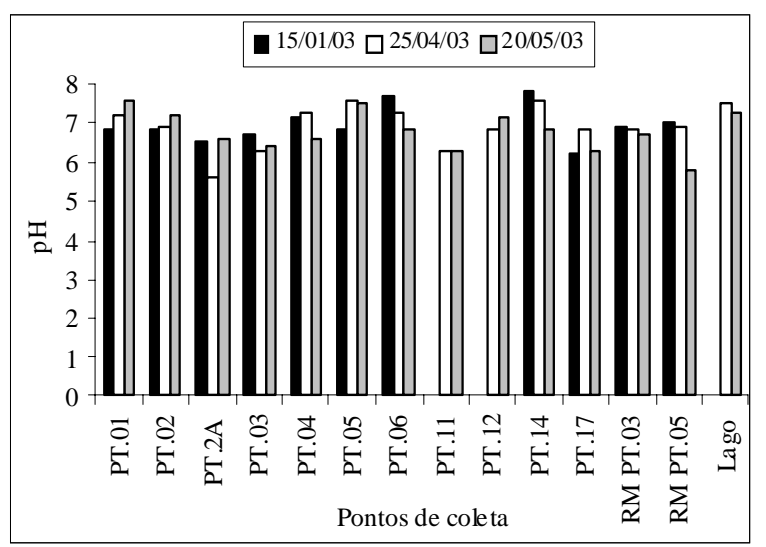

Figura 6 - pH no período chuvoso 


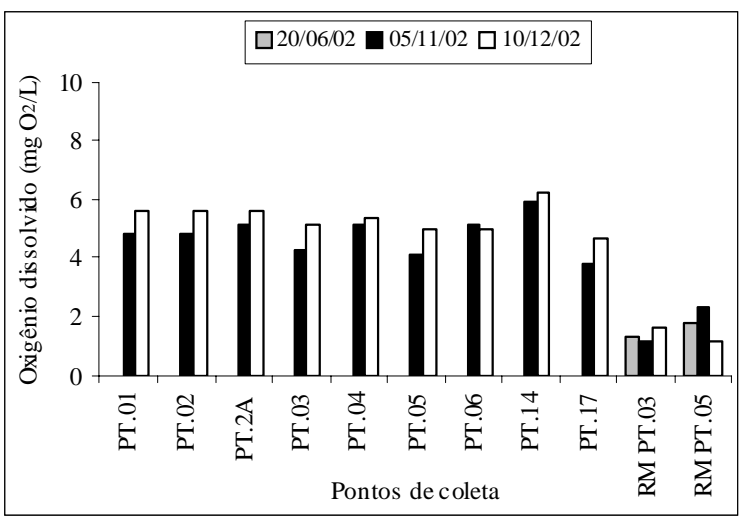

Figura 7 - Oxigênio dissolvido no período seco

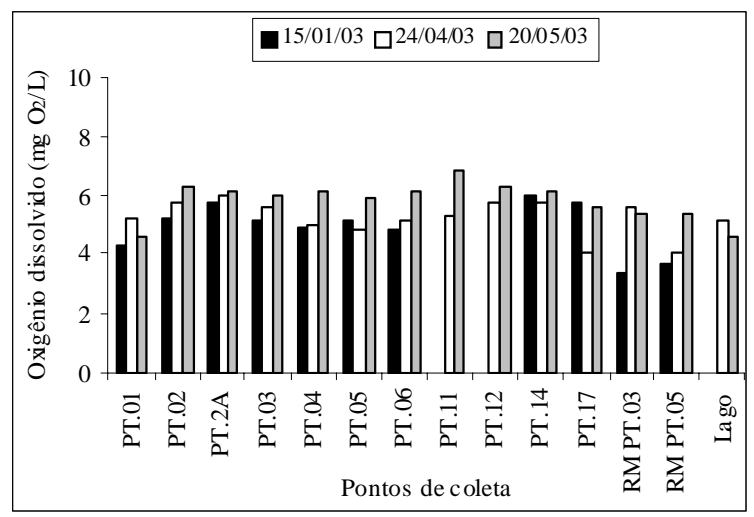

Figura 8 - Oxigênio dissolvido no período chuvoso
A legislação brasileira em vigor estabelece limites de 6,0, 5,0, 4,0 e 2,0 mg/L de OD para as águas de classe 1, 2, 3, e 4, respectivamente. Verifica-se que durante o período seco, as águas do riacho dos Macacos não se enquadram nas classes 1 , 2, 3, e 4 de águas doces.

\section{Nitrato}

As águas subterrâneas apresentam geralmente teores de nitrato entre $0,1 \mathrm{e}$ $10 \mathrm{mg} / \mathrm{L}$, porém, em águas poluídas, osteores podem chegar a $1.000 \mathrm{mg} / \mathrm{L}$ (Santos, 2000). Segundo a Portaria No 518 de 25 de Março de 2004, água destinada ao abastecimento humano não deve conter mais que $10 \mathrm{mg} \mathrm{N}-\mathrm{NO}_{3}{ }^{-} / \mathrm{L}$. Concentrações elevadas podem causar metahemoglobinemia (cianose) em crianças.

O nitrato pode chegar às águas subterrâneas através de esgotos domésticos e industriais ou pela lixiviação de áreas agrícolas. Elevado teor de nitrato associado com um teor de cloreto é uma forte indicação de poluição de águas subterrâneas por águas residuárias domésticas (Driscoll, 1987).

Durante o período seco (Figura 8), nas águas dos poços, as concentrações de nitrato se mantiveram entre $15,6 \mathrm{mg} \mathrm{N}-\mathrm{NO}_{3}{ }^{-} / \mathrm{L}$, no PT $2 \mathrm{~A}$, e $0,8 \mathrm{mg} \mathrm{N}-\mathrm{NO}_{3}^{-} / \mathrm{L}$, no PT 17 . No período chuvoso (Figura 9), essas concentrações variaram entre $5,8 \mathrm{mg} \mathrm{N}-\mathrm{NO}_{3}^{-} / \mathrm{L}$, no PT 2A, e 0,3 mg N-NO ${ }_{3}^{-} / \mathrm{L}$ ), no PT 12.

Considerando o nível máximo de nitrato permitido pela legislação (10 mg $\left.\mathrm{N}_{-} \mathrm{NO}_{3}^{-} / \mathrm{L}\right)$, verifica-se que o PT 2A apresentou concentraçōes superiores no período seco $\left(15,6 \mathrm{mg} \mathrm{N}^{-\mathrm{NO}_{3}} / \mathrm{L}\right)$, o que indica poluição por esgotos domésticos devido à proximidade de mananciais superficiais poluídos. A maior concentração de nitrato no riacho dos Macacos aconteceu durante o período seco,

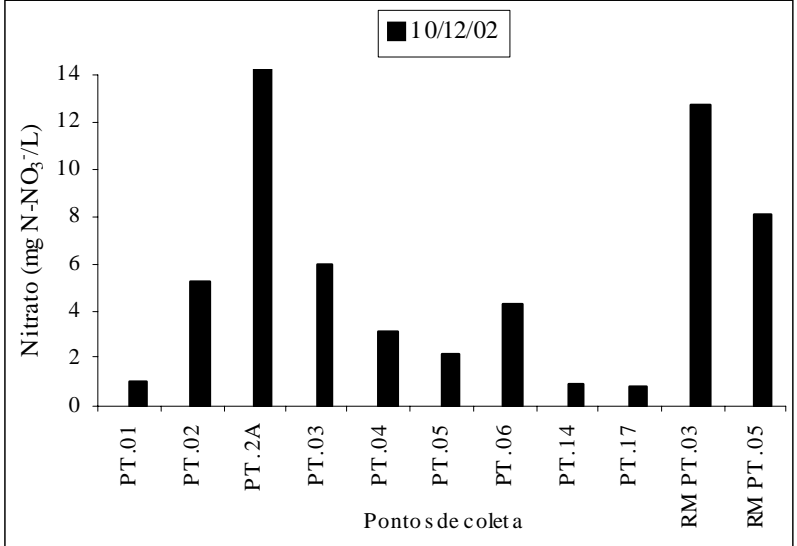

Figura 9 - Nitrato no período seco

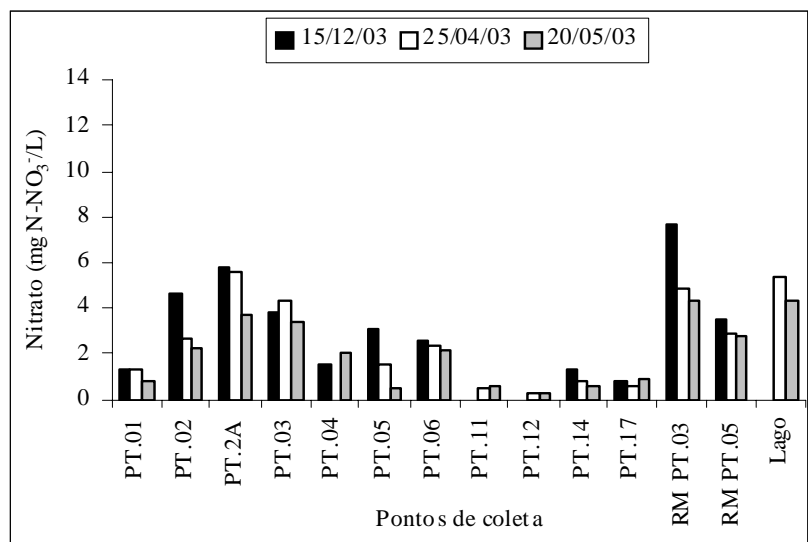

Figura 10 - Nitrato no período chuvoso

atingindo 12,8 $\mathrm{mg} \mathrm{N}-\mathrm{NO}_{3}^{-} / \mathrm{L}$. No período chuvoso, considerando a média dos dois pontos amostrados, essa concentração caiu para $4,3 \mathrm{mg} \mathrm{N}-\mathrm{NO}_{3}^{-} / \mathrm{L}$. No Lago da Timbaúba, amostrado apenas durante o período chuvoso, a media foi $4,8 \mathrm{mg} \mathrm{N}^{-\mathrm{NO}_{3}}-\mathrm{L}$.

De acordo com a Resolução No 357 do CONAMA, as águas do riacho dos Macacos durante o período seco e chuvoso se enquadram no limite de $10 \mathrm{mg} \mathrm{N}-\mathrm{NO}_{3}{ }_{3}^{-} / \mathrm{L}$ estabelecido para águas de classes doces.

\section{Amônia}

Durante o período seco (Figura 10), somente o PT 17 apresentou valores (1,4 $\left.\mathrm{mg} \mathrm{NH}_{3} / \mathrm{L}\right)$ condizentes com a Portaria No 518 de 25 de Março de 2004, que estabelece uma concentração abaixo de $1,5 \mathrm{mg} \mathrm{N}-\mathrm{NH}_{3} / \mathrm{L}$.

Durante o período chuvoso (Figura 11) as concentrações de amônia nos poços variaram de $3,0 \mathrm{mg} \mathrm{N}-\mathrm{NH}_{3} / \mathrm{L}$, no PT 06, e 0,7 mg N-NH $/$ L, no PT 11. Com base na Portaria No 518 de 25 de 
Março de 2004, considerando valores médios, os poços (PT 01, PT 2A, PT 03, PT 05, PT 06 e PT 17), apresentaram valores acima do limite de $1,5 \mathrm{mg} \mathrm{N}-\mathrm{NH}_{3} / \mathrm{L}$ estabelecido para águas de consumo humano. Com relação a esse parâmetro, tais poços apresentam indícios de poluição por matéria orgânica. Na época da perfuração (1976), o PT 04 apresentou traços de amônia e durante o monitoramento a concentração média observada foi de $1,3 \mathrm{mg} \mathrm{N}-\mathrm{NH}_{3} / \mathrm{L}$.

A concentração de amônia no riacho dos Macacos é mais elevada; duran-te o período seco (figura 10), o mínimo foi de $9 \mathrm{mg}$ $\mathrm{N}-\mathrm{NH}_{3} /$ Le o máximo, $12,8 \mathrm{mgN}-\mathrm{NH}_{3} / \mathrm{L}$.

A presença de amônia no riacho dos Macacos pode ser atribuída aos constantes lançamentos de efluentes domésticos in natura como também ao uso de fertilizantes nitrogenados na área, processos erosivos e lixiviação dos solos agrícolas.

De acordo com a Resolução No 357 do CONAMA, o riacho dos Macacos não se enquadra nas classes 1,2 , ou 3 , cujo valor máximo é de $0,02 \mathrm{mg} / \mathrm{L}$, podendo ser enquadrado na classe 4 (águas destinadas à navegação), para qual um valor limite de amônia não foi estipulado.

Durante o período chuvoso (Figura 11), no riacho e no Lago da Timbaúba, as concentraçóes variaram de $8,9 \mathrm{mg} \mathrm{N}-\mathrm{NH}_{3} / \mathrm{L}$, no ponto vizinho ao PT 03, e 11,5 mg N-NH $/$ / , no ponto vizinho ao PT 05 . Neste período as águas do riacho também não se enquadram dentro das classes 1, 2, ou 3, classificação da Resolução No 357 do CONAMA; assim, tanto o riacho dos Macacos como o Lago da Timbaúba encontram-se poluídos por esgotos domésticos.

\section{Alcalinidade}

A alcalinidade das águas subterrâneas, geralmente, situa-se entre $100 \mathrm{e}$ $300 \mathrm{mg} \mathrm{CaCO}_{3} / \mathrm{L}$, somente em casos excepcionais pode atingir $1000 \mathrm{mg} \mathrm{CaCO} / \mathrm{L}$ (Custodio e Llamas, 1983).

Para o período seco (Figura 12), os poços mostraram variação na média de 17,3 mg $\mathrm{CaCO}_{3} / \mathrm{L}$, no PT 2A, e 157,2 mg $\mathrm{CaCO}_{3} / \mathrm{L}$, no PT 06. No período chuvoso (figura 13), a alcalinidade foi superior em todos os poços, apresentando valores médios mínimo de $41,1 \mathrm{mg} \mathrm{CaCO} / \mathrm{L}$ (PT 2A) e máximo de 169,8 mgCaCO $/ \mathrm{L}$ (PT 06). O aumento da alcalinidade das águas dos poços durante esse período pode estar relacionado á entrada de águas novas bicarbonatadas.

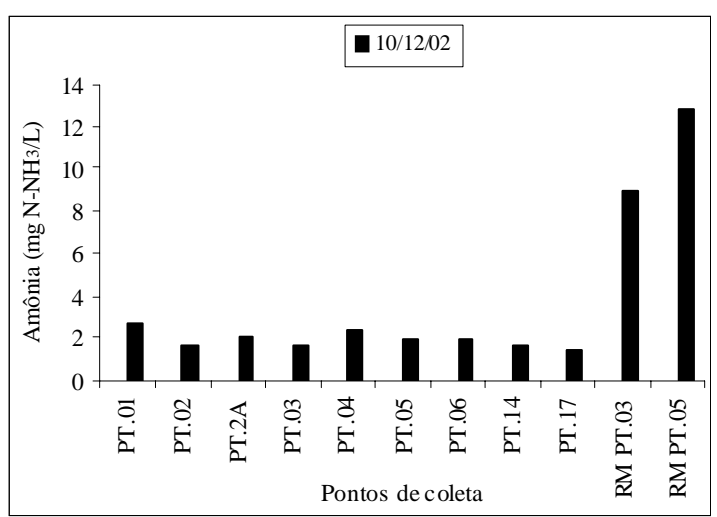

Figura I I - Amônia no período seco

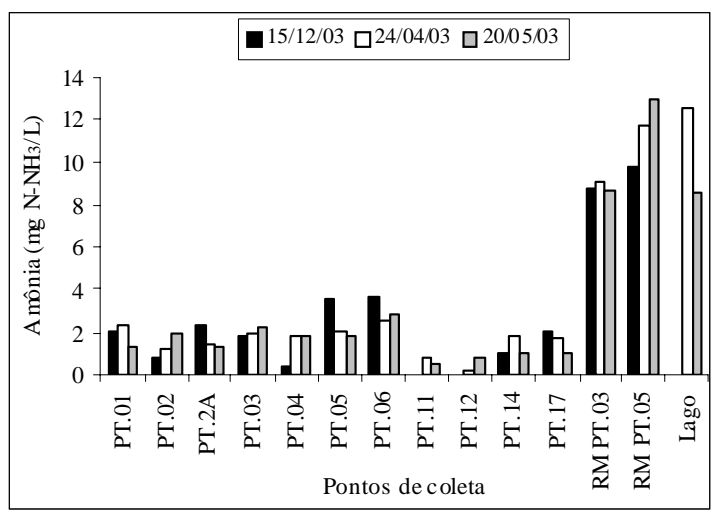

Figura I2 - Amônia no período chuvoso

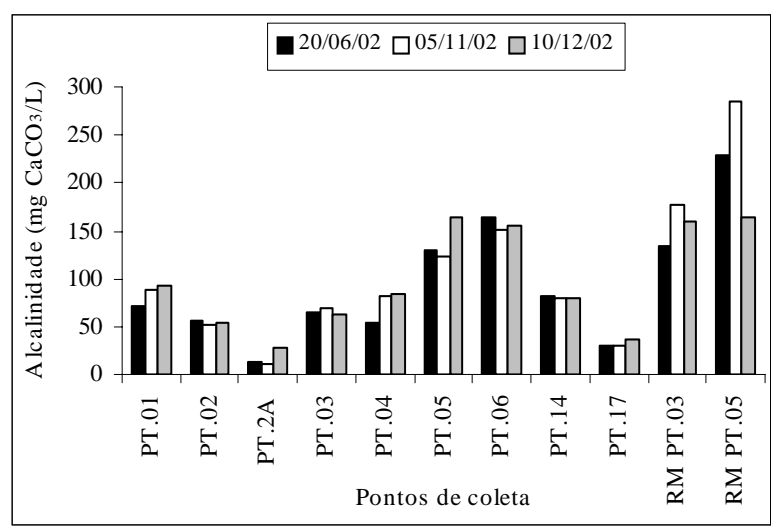

Figura I 3 - Alcalinidade total no período seco

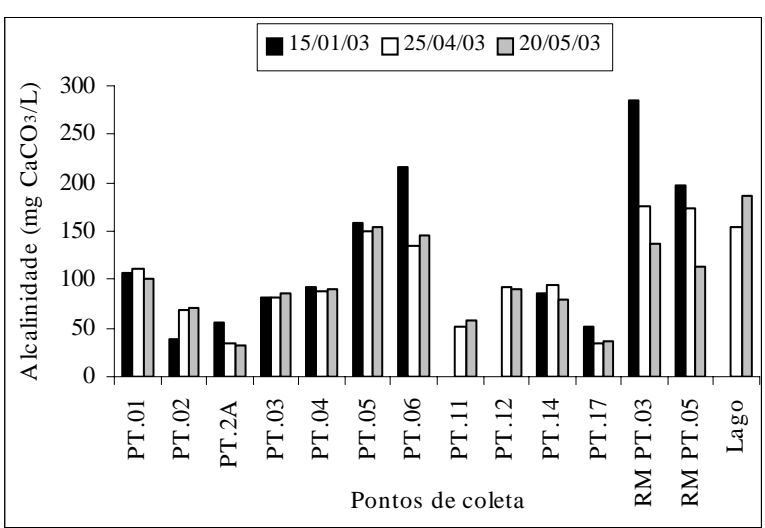

Figura I4 - Alcalinidade no período chuvoso 
Durante o período seco, no riacho dos Macacos, os valores médios de alcalinidade situaram-se entre $156,4 \mathrm{mg} \mathrm{CaCO}_{3} / \mathrm{L}$ e $226,3 \mathrm{mg}$ $\mathrm{CaCO}_{3} / \mathrm{L}$. Já no período chuvoso, os valores médios variaram de 161,6 $\mathrm{mgCaCO}_{3} / \mathrm{L}$ a $199,7 \mathrm{mg} \mathrm{CaCO}_{3} / \mathrm{L}$ (Figuras 12 e 13). Constata-se, portanto, que não há mudanças significativas no riacho dos Macacos em função da estação. A alcalinidade é determinada mais pelos de efluentes domésticos e industriais do que pelas águas naturais.

\section{Dureza}

De acordo com os padrões de qualidade da água para consumo humano (Portaria No 518 de 25 de Março de 2004), o limite máximo desejável é de $500 \mathrm{mg} \mathrm{CaCO}_{3} / \mathrm{L}$.

Os valores de dureza para as águas subterrâneas estão, geralmente, situados entre 10 e $300 \mathrm{mgCaCO}_{3} / \mathrm{L}$, podendo atingir $1000 \mathrm{mgCaCO}_{3} / \mathrm{L}$ e, em casos excepcionais, $2000 \mathrm{mgCaCO}_{3} / \mathrm{L}$. As águas subterrâneas podem ser classificadas, em termos de dureza $\left(\mathrm{mg} \mathrm{CaCO}_{3} / \mathrm{L}\right)$, como "branda" $(<50)$, "pouco dura" (50-100), "dura" (100-200) e "muito dura” (>200) (Custodio \& Lamas, 1983).

Durante o período seco (Figura 14), a dureza das águas dos poços, considerando valores médios, se manteve bastante variável. O valor menor foi $48 \mathrm{mgCaCO}_{3} / \mathrm{L}$, no PT 17, e o maior, $138 \mathrm{mgCaCO}_{3} / \mathrm{L}$, no PT 06. No período chuvoso (Figura 15), a dureza das águas dos poços aumentou em quase todos os poços, o maior valor médio foi de $156,6 \mathrm{mg} \mathrm{CaCO}_{3} / \mathrm{L}$, PT 2A, e o menor, de 53,6 $\mathrm{mgCaCO}_{3} / \mathrm{L}$, PT 17. Mesmo assim, as águas dos poços, também considerando valores médios, mantêm a mesma classificação ("dura” na maioria dos poços), com exceção do PT 17, que passa a ter águas "branda".
De acordo com a Portaria No 518 de 25 de março de 2004, as águas de todos os poços estão dentro do limite estabelecido ( $500 \mathrm{mg} \mathrm{CaCO}_{3} / \mathrm{L}$ ) para águas de consumo humano.

Durante o período seco, no riacho dos Macacos, considerando os dois pontos amostrados, a dureza média foi de $216 \mathrm{mg} \mathrm{CaCO}_{3} / \mathrm{L}$. Já no período chuvoso, o valor da dureza duplicou com relação ao período seco, atingindo valores em torno de $426 \mathrm{mg} \mathrm{CaCO}_{3} / \mathrm{L}$.

\section{Cloreto}

As concentraçōes de cloreto verificadas nas águas dos poços durante o período seco se mantiveram bastante variáveis (Figura 16). A média menor foi 9,5 mg/L, nos poços PT 14 e PT 17, e maior, 61,5 mg/L, no PT 2A. Durante o período chuvoso, as concentrações de cloreto aumentaram nos poços PT 01, PT 2A, PT 03, PT 04, PT 06, PT 14 e PT 17 e diminuíram nos poços PT $02 \mathrm{e}$ PT 05 (figura 17). Na época da perfuração (1976), o PT 04 apresentou concentração de cloreto $8 \mathrm{mg} / \mathrm{L}$ e durante o monitoramento o valor médio observado foi $39,55 \mathrm{mg} / \mathrm{L}$. Porém, as águas de todos os poços atendem ao limite de $250 \mathrm{mg} / \mathrm{L}$, estabelecido na Portaria No 518 de 25 de março de 2004.

No período seco, as concentrações de cloreto no riacho dos Macacos foram de $67 \mathrm{mg} / \mathrm{L}$ e 348,3 mg/L (figura 16). No primeiro ponto de coleta, as águas do riacho dos Macacos não se enquadram dentro dos limites estabelecidos para águas doces. Durante o período chuvoso, no riacho dos Macacos, o menor valor foi $82,7 \mathrm{mg} / \mathrm{L}$ e o maior, de $209,7 \mathrm{mg} / \mathrm{L}$ (Figura 17). No primeiro ponto ocorreu uma diminuição na concentração de cloreto, provavelmente devido à diluição durante as chuvas. Nesse período, as águas atendem ao limite estabelecido pela Resolução No 357 do CONAMA para águas doces, que fixa o valor em $250 \mathrm{mg} / \mathrm{L}$.

\section{Demanda bioquímica de oxigênio e demanda química de oxigênio}

Durante o período seco (Figura 18), o valor maior de DBO observada no riacho dos Macacos foi de $244 \mathrm{mg} / \mathrm{L}$ e o menor de $15 \mathrm{mg} / \mathrm{L}$. Já durante o período chuvoso com uma melhor homogeneização, o valor mínimo foi $65 \mathrm{mg} / \mathrm{L}$ e o valor máximo $155 \mathrm{mg} / \mathrm{L}$. Em termos de média, houve um decréscimo durante o período chuvoso, que pode ser explicado pela diluição da matéria orgânica devido às chuvas. Com relação à DBO medida, o riacho dos Macacos não se enquadra nas classes especial, 1, 2, 3 e 4 de águas doces, conforme o que estabelece a Resolução No 357 do CONAMA.

As concentraçōes de DQO (Figura 19) nas águas do riacho dos Macacos, durante o período seco, variaram de $89 \mathrm{mg} / \mathrm{L}$ a $456 \mathrm{mg} / \mathrm{L}$. Durante o período chuvoso não houve grandes variaçóes com relação ao período seco. Os valores de DBO e DQO se apresentaram bastante elevados, confirmando que o riacho dos Macacos recebeu carga orgânica poluidora.

De acordo com a Resolução No 357 do CONAMA, a $\mathrm{DBO}_{5}$ (medida por 5 dias a $20^{\circ} \mathrm{C}$ ), pode atingir $3 \mathrm{mg} / \mathrm{L}$ para as classes de águas doces (classes especial e 1), $5 \mathrm{mg} / \mathrm{L}$ para classe 2, $10 \mathrm{mg} / \mathrm{L}$ para classe 3; para a classe 4 não faz referência.

\section{Coliformes totais e termotolerantes}

As concentrações de coliformes totais e termotolerantes nas águas dos poços apresentaram-se bastante variáveis ao

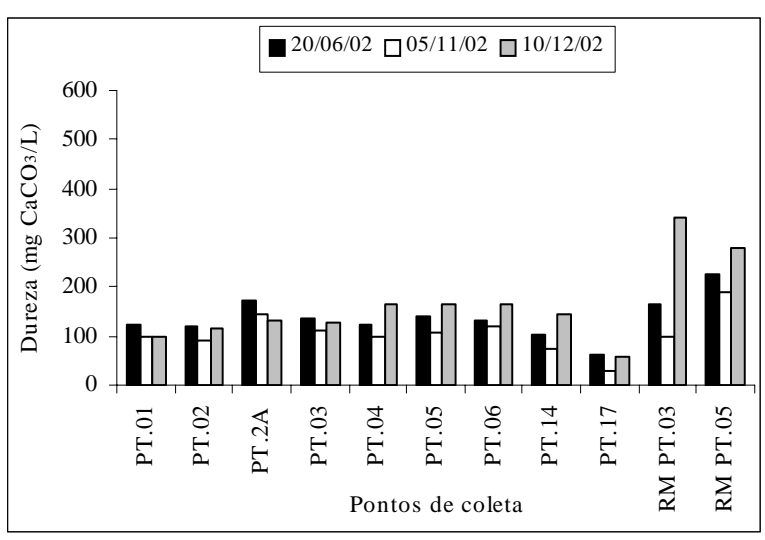

Figura I5 - Dureza total no período seco

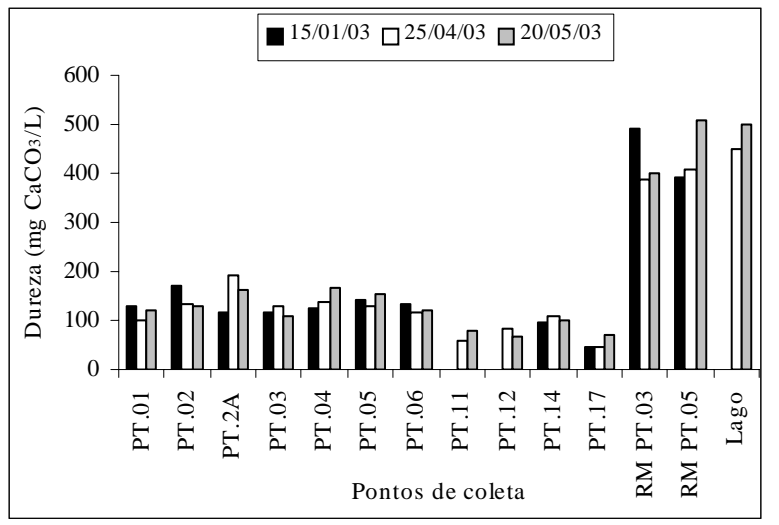

Figura I 6 - Dureza total no período chuvoso 


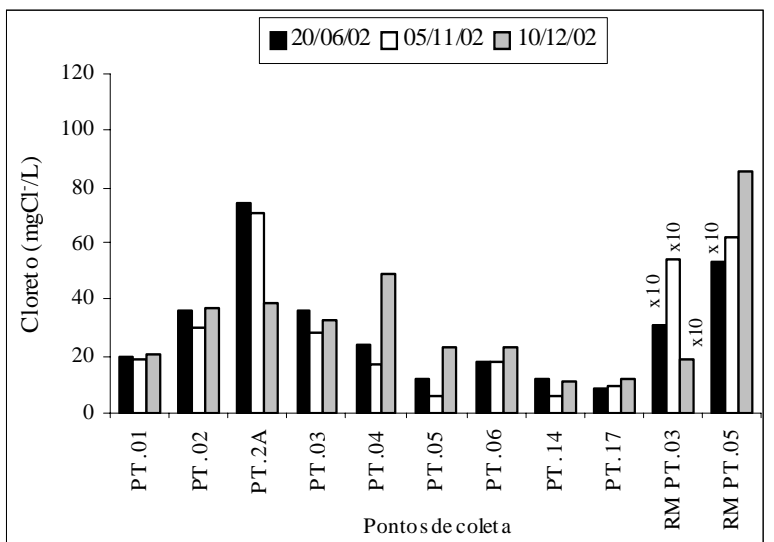

Figura 17 - Cloreto no período seco

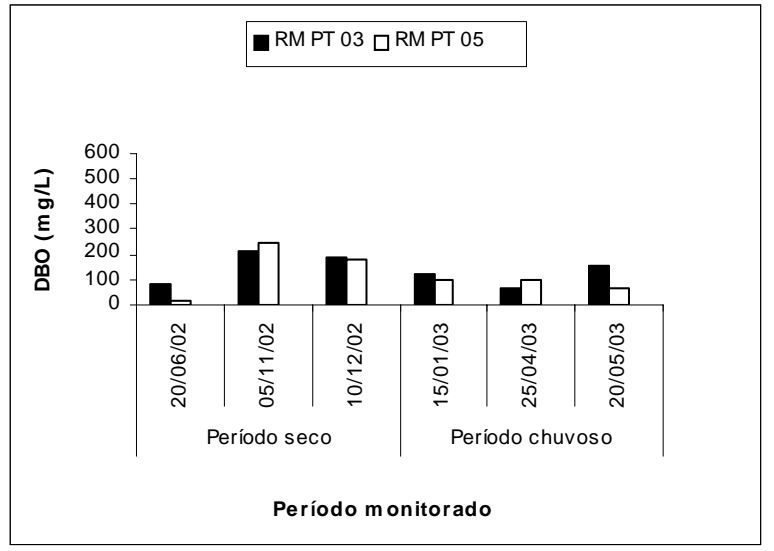

Figura 19 - DBO no riacho dos Macacos

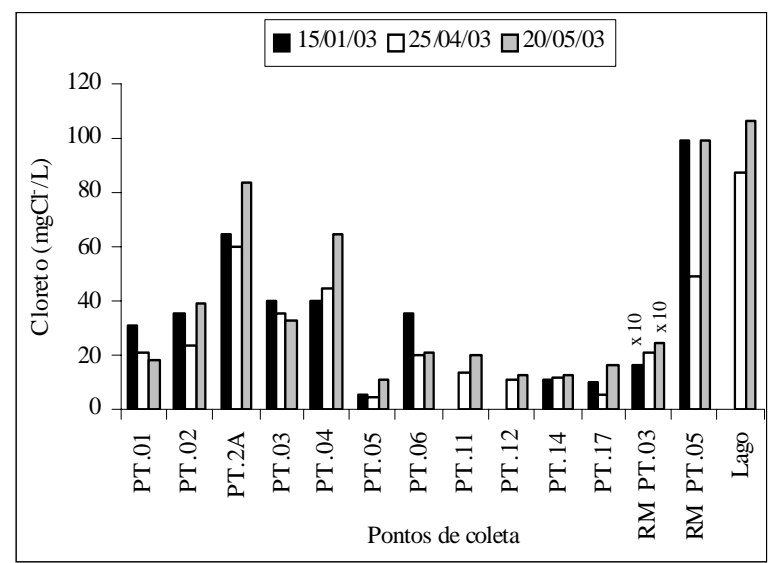

Figura I 8-Cloreto no período chuvoso

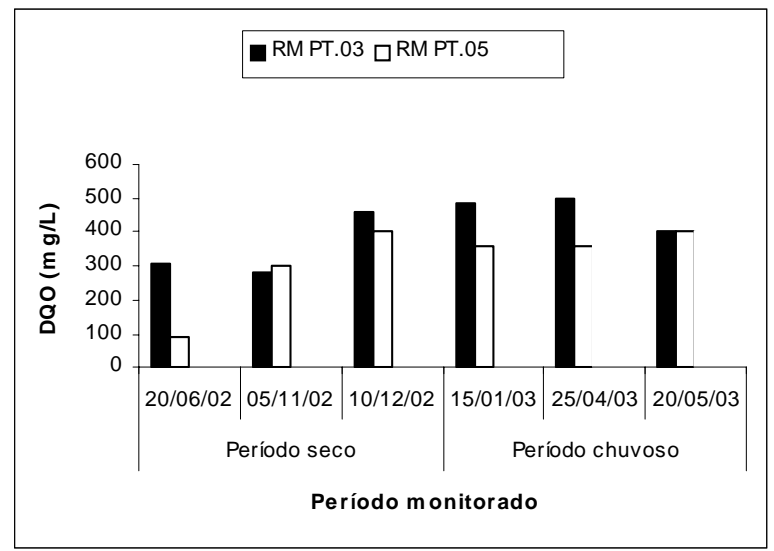

Figura 20 - DQO do riacho dos Macacos longo do período de monitoramento. Dos onze poços amostrados, apenas dois (PT 11 e PT 12), não apresentaram coliformes em nenhuma das coletas. Tais poços, embora localizados fora da parte da bateria estudada, foram incluídos no monitoramento com o propósito de comparação, visto que se encontram em boas condições sanitárias e distantes dos focos de poluição.

De acordo com a tabela 1 , os poços PT 2A e PT 05, apresentam maior incidência de coliformes totais e termotolerantes (39 e $76 \mathrm{NMP} / 100 \mathrm{~mL}$ ) respectivamente. No PT $2 \mathrm{~A}$ pode estar relacionado com a proximidade do poço com o riacho dos Macacos $(17 \mathrm{~m})$ e a pouca profundidade, de apenas $32 \mathrm{~m}$. No PT 05 suspeitamos ter ocorrido contaminação da amostra, já que valores elevados não se repetiram. Os poços PT 17 , PT 02 e PT 14 também apresentaram concentraçóes de coliformes totais e termotolerantes bastante variáveis, se repetindo ao longo do monitoramento. $\mathrm{O}$ PT 17 situa-se a $27 \mathrm{~m}$ do lago da Timbaúba, que recebe contribuições fluviais, é usado para dessedentação de animais e para lançamentos de resíduos sóli- dos das proximidades. O PT 02 está localizado a $70 \mathrm{~m}$ do riacho dos Macacos, provável fonte de poluição. O PT 14 apresenta apenas coliformes totais em pequenas densidades, porém, repetindo-se em três coletas. O PT 03 apresenta apenas coliformes totais apesar de estar localizado a $13 \mathrm{~m}$ do riacho dos Macacos, a jusante de lançamentos de efluentes brutos.

Os poços PT 01, PT 04, PT 05 e PT 06 apresentaram pouca e variável concentração de coliformes. Alguns desses poços estão localizados em áreas de poluição próxima, com córregos de esgoto visíveis na vizinhança.

No riacho dos Macacos e no lago da Timbaúba, a concentração de coliformes totais e termotolerantes, em ambos os períodos de amostragem, superam o limi- te máximo detectado pelo método cromogênico, de 2.419 NMP/100mL (Tabela 1).

\section{Simulação computacional com uso do MODPATH}

A simulação foi feita considerando apenas a bateria de poços do riacho dos Macacos, que apresenta problemas ambientais. A área de domínio do modelo, de extensão $11.000 \mathrm{~m}$ x $13.000 \mathrm{~m}$, foi escolhida de tal forma que a área de interesse, que corresponde à bateria de poços, ficasse centrada na malha para não sofrer interferência dos contornos durante as simulações. Foi traçado um círculo em torno do poço, com raio igual à distância entre o poço e riacho dos Macacos, onde as partículas (bactérias) transportadas por advecção são dispersas. As linhas de trajetória das partículas mergulham em direção aos filtros dos poços. As partículas mais rápidas levam um tempo entre 15 e 100 dias para atingir o filtro do poço (Tabela 2).

As concentraçóes de coliformes apresentam variações temporais diferenciadas, indicando uma dependência com a carga de poluentes existentes nas proximidades de cada poço. No final do período chuvoso verifica-se uma redução das concentraçóes.

Os tempos para as partículas atingirem os filtros dos poços são relativamente reduzidos, principalmente nos poços $\mathrm{PT}$ 03 e PT 17, mais próximos das fontes poluidoras, considerando a alta carga bacteriana do riacho dos Macacos e a meia 
Tabela I - Coliformes totais (CT) e termotolerantes (TT) em NMP/I 00mL nas águas dos poços, lago e riacho dos Macacos em Juazeiro do Norte - CE, nos períodos seco e chuvoso

\begin{tabular}{ccccccccccc}
\hline Pontos & \multicolumn{9}{c}{ Período Seco } & \multicolumn{7}{c}{ Período Chuvoso } \\
de coleta & $20 / 06 / 02$ & $05 / 11 / 02$ & \multicolumn{1}{c}{$15 / 01 / 03$} & \multicolumn{2}{c}{$10 / 04 / 03$} & $25 / 05 / 03$ \\
& CT & TT & CT & TT & CT & TT & CT & TT & CF & TT \\
\hline PT 01 & $*$ & $*$ & 5 & A & A & A & A & A & A & A \\
PT 02 & 10 & 1 & 27 & A & 23 & A & 2 & A & 5 & 2 \\
PT 2A & 11 & A & 39 & 3 & 17 & 6 & 17 & A & 23 & 6 \\
PT 03 & 12 & A & A & A & 3 & A & 6 & A & 4 & A \\
PT 04 & A & A & A & A & A & A & A & A & 4 & 1 \\
PT 05 & A & A & 76 & 1 & A & A & A & A & A & A \\
PT 06 & A & A & A & A & A & A & 4 & A & $*$ & $*$ \\
PT 11 & $*$ & $*$ & $*$ & $*$ & A & A & A & A & A & A \\
PT 12 & $*$ & $*$ & $*$ & $*$ & A & A & A & A & A & A \\
PT 14 & 7 & A & $*$ & $*$ & 3 & A & 3 & A & 3 & A \\
PT 17 & $*$ & A & 5 & $*$ & 31 & A & 5 & A & 6 & 2 \\
RM (PT 03) & $>2419$ & $>2419$ & $>2419$ & $>2419$ & $>2419$ & $>2419$ & $>2419$ & $>2419$ & $>2419$ & $>2419$ \\
RM (PT 05) & $>2419$ & $>2419$ & $>2419$ & $>2419$ & $>2419$ & $>2419$ & $>2419$ & $>2419$ & $>2419$ & $>2419$ \\
Lago & $*$ & $*$ & $*$ & $*$ & $>2419$ & $>2419$ & $>2419$ & $>2419$ & $>2419$ & $>2419$ \\
\hline * ponto năo amostrado NMP: Número Mais Provável CT: Coliformes Totais TT: Coliformes Termotolerantes \\
A: Ausência $(>2419):$ Valor máximo detectado pelo método cromogênico & & &
\end{tabular}

Tabela 2 - Tempo mínimo que as partículas levam para atingir o filtro dos poços em transporte advectivo a partir do riacho dos Macacos

\begin{tabular}{ccc}
\hline Poço & \multicolumn{2}{c}{ Tempo (dias) } \\
& Período seco & Período chuvoso \\
\hline PT 02 & 90 & 90 \\
PT 03 & 20 & 30 \\
PT 05 & 80 & 80 \\
PT 06 & 100 & 100 \\
PT 17 & 15 & 15 \\
\hline
\end{tabular}

vida de coliformes em água subterrânea de aproximadamente 8 dias (Edberg et al, 1997).

Segundo Auer e Niehaus (1993), as bactérias do grupo coliforme, em um dado ambiente, têm seu decaimento acelerado por agentes físicos, químicos e biológicos, dentre eles a radiação solar, a temperatura, o $\mathrm{pH}$, a salinidade e a bacteriofagocitose. No caso da água, o decaimento pode ser mais lento em ambiente turvo ou escuro com temperatura próxima a da atmosfera. Nas águas subterrâneas, as bactérias estão protegidas de agentes que aceleram o decaimento. Desta maneira, aumenta a permanência das bactérias neste meio e o perigo de conta- minação bacteriana pelo riacho dos Macacos.

\section{Caracterização isotópica das águas subterrâneas: oxigênio- 18}

Foram feitas medidas de ${ }^{18} \mathrm{O}$ para avaliar o grau de influência de águas superficiais nas águas bombeadas pelos poços. Em águas superficiais este isótopo é enriquecido pela evaporação (que vaporiza com uma pequena preferência as moléculas mais leves), resultando em um $\delta^{18} \mathrm{O}$ mais elevado (aqui, menos nega-tivo).

Valores em torno de $-3,2 \%$ representam água de chuva atual infiltrada ra- pidamente nos solos de alta permeabilidade (Tabela 3). Os valores mais baixos, para PT 06, PT 05 e PT 14 (25/03/03), representam misturas das águas recentes de origem pluvial com paleoáguas ascendentes de um fluxo regional. Estas paleoáguas têm $\delta^{18} O$ mais baixo, pois são marcados pela temperatura mais baixa $\left(\cong 5^{\circ} \mathrm{C}\right)$ no final do Pleistocênico.

Os valores mais altos (em negrito Tabela 2) representam misturas de águas recentes de origem pluvial com águas superficiais (marcados pela evaporação com $\delta^{18} \mathrm{O}$ mais elevado): PT $2 \mathrm{~A}(26 / 08 / 02$; 25/03/03), РT 03 (10/06/02; 26/08/02), PT $07(10 / 06 / 02)$, PT $14(26 / 08 / 02)$ e 
Tabela 3 - Oxigênio- 18 ( $\delta^{18}$ O\%o(VSMOW) nas águas dos poços em Juazeiro do Norte

\begin{tabular}{ccccc}
\hline Pontos & \multicolumn{2}{c}{ Período Seco } & \multicolumn{2}{c}{ Período Chuvoso } \\
de coleta & $10 / 06 / 02$ & $26 / 08 / 02$ & $25 / 03 / 03$ & $24 / 04 / 03$ \\
\hline PT 01 & $*$ & $-2,80$ & $-3,07$ & $-3,00$ \\
PT 02 & $*$ & $*$ & $-3,17$ & $-3,32$ \\
PT 2A & $*$ & $-2,53$ & $-2,89$ & $-3,27$ \\
PT 03 & $-2,55$ & $-2,73$ & $-3,02$ & $-3,08$ \\
PT 04 & $*$ & $*$ & $-3,04$ & $*$ \\
PT 05 & $*$ & $*$ & $-3,59$ & $-3,43$ \\
PT 06 & $-3,62$ & $*$ & $*$ & $*$ \\
PT 07 & $-2,77$ & $*$ & $*$ & $*$ \\
PT 11 & $*$ & $*$ & $-3,10$ & $-3,11$ \\
PT 12 & $*$ & $*$ & $-3,22$ & $-3,24$ \\
PT 14 & $*$ & $-2,88$ & $-3,67$ & $*$ \\
PT 17 & $*$ & $-2,57$ & $-2,91$ & $-3,01$ \\
\hline
\end{tabular}

* ponto não amostrado ou não analisado PT: poço tubular

recentes de origem pluvial com águas superficiais (marcados pela evaporação com $\delta^{18} O$ mais elevado): PT 2A (26/08/02; 25/03/03), РT $03(10 / 06 / 02 ; 26 / 08 / 02)$, PT $07(10 / 06 / 02)$, PT $14(26 / 08 / 02)$ e PT 17 (26/08/02; 25/03/03). Conseqüentemente, os poços com $\delta^{18} O$ mais elevado, PT 2 A e PT 17 , se destacam também nos coliformes totais (Figura 20). Assim, as medidas de $\delta^{18} O$ comprovam para a área dos poços, a forte recarga do aqüífero pelo riacho.

\section{CONCLUSÕES}

A qualidade química das águas de parte dos poços amostrados apresenta indícios de poluição por esgotos domésticos. Constatou-se uma sazonalidade na condutividade elétrica das águas dos poços. No riacho dos Macacos, durante o período seco, observou-se variaçôes acentuadas, o menor valor foi $706 \mu \mathrm{S} / \mathrm{cm}$ e o maior $1.087 \mathrm{i} S / \mathrm{cm}$. No PT $2 \mathrm{~A}$ as medidas de nitrogênio de amônia e de nitrato ultrapassaram os valores máximos permitidos pela Portaria 518 do Ministério da Saúde. As águas da maioria dos poços foram classificadas como de dureza moderada com valores variando entre 56 e $149 \mathrm{mgCaCO}_{3} / \mathrm{L}$. Já as águas do riacho dos Macacos foram classificadas como águas duras.

O riacho dos Macacos pode ser enquadrado dentro das classes de águas doces $(1,2,3$, e 4$)$ de acordo com a Resolução No 357 do CONAMA, considerando os parâmetros: $\mathrm{pH}$ e cloreto. Os de- mais parâmetros analisados não se enquadram em nenhuma das classes de águas doces. No riacho dos Macacos e no Lago da Timbaúba, em todas as análises realizadas, constataram-se concentraçôes de coliformes totais e termotolerantes maiores que a quantificável pelo método cromogênico (> 2.419 NMP/100mL).

Embora sendo facilmente possível a remoção destas bactérias por tratamento, a Portaria No. 518 do Ministério da Saúde define-as como padróes de potabilidade e indicadores de contaminação fecal, exigindo-se ausência em água para consumo humano. Assim, apesar dos números relativamente baixos, consideramos a sua presença mais um indício de contaminação da água subterrânea pelo riacho dos Macacos.

Medidas de oxigênio-18 comprovam uma forte interação hidráulica entre o riacho dos Macacos e o aqüífero Rio da Batateira. Os poços PT 2A e PT 17, que receberam mais contribuição de águas superficiais, reconhecíveis pelos valores mais elevados de $\delta^{18} \mathrm{O}$, também apresentaram coliformes totais e termotolerantes com concentração máxima de, respectivamente, 39NMP/100mLe6 NMP/100mL e de $31 \mathrm{NMP} / 100 \mathrm{~mL}$ e $6 \mathrm{NMP} / 100 \mathrm{~mL}$.

Em geral, as águas captadas por poços profundos não apresentam coliformes fecais devido à baixa velocidade e a capacidade filtrante do meio aqüífero. Dessa forma, a presença de coliformes nessas águas indica um perigo eminente de contaminação por elementos químicos conservativos.
Na simulação computacional com o aplicativo MODPATH, o tempo mínimo para o transporte advectivo de partículas do manancial superficial até o filtro dos poços varia de aproximadamente 15 a 100 dias. Estes tempos são relativamente reduzidos considerando a meia vida dos coliformes em águas subterrâneas, de aproximadamente 8 dias, e a elevada carga bacteriana no riacho dos Macacos e no lago da Timbaúba. Dessa forma, a contaminação dos poços por estes mananciais se torna evidente.

Assim, o riacho dos Macacos e o lago da Timbaúba constituem os elos principais na conexão entre a água superficial e a água subterrânea e necessitam de elevada atenção e proteção. $\mathrm{Na}$ atualidade, eles são as principais entradas de contaminação química e bacteriológica das águas subterrâneas, funcionando como fontes persistentes e contínuas de poluição das águas exploradas para consumo humano. Portanto, devem ser tomadas precauçôes para evitar o despejo de esgoto e lixo na área. O perigo que a bateria de poços e o aquífero rio da Batateira correm no caso de contaminação do riacho dos Macacos por matéria tóxica persistente, é elevado.

\section{AGRADECIMENTOS}

Os autores agradecem ao $\mathrm{CNPq}$, à FUNCAP, à Agência Reguladora de Serviços Públicos Delegados do Estado do Ceará-ARCE, ao Laboratório de Saneamento - Labosan da UFC, à Companhia de Água e Esgoto do Estado do Ceará - 
Cagece, à Universidade Regional do Cariri - Urca (nas pessoas dos professores Jackson Antero da Silva e Rodolfo José Sabiá) e a Profa. Marlúcia Freitas Santiago da UFC.

\section{REFERÊNCIAS}

APHA. AWWA. WPCF. Standard methods for the examination of water and wastewater. 19 ed. Washington, D.C.: American Public Health Association, American Water Works Association, Water Pollution control Federation, 1134p. 1995.

AUER, M. T.; NIEHAUS, S. L. Modeling fecal coliform bacteria-I field and laboratory determination of loss kinetics. Water Resources, v. 27, n. 4 , p. 693-701, 1993.

CEARÁ. Companhia de Água e Esgoto do Estado do Ceará - Cagece. Dados de populaçōes e economias de esgoto-2003. Juazeiro do Norte: 3p. CAGECE 2003.

CONAMA. Resolução no 357, de 2005. Estabelece a classificação das águas doces, salobras e salinas do Brasil. Diário Oficial da União. Brasília, DF, 2005.

CUSTODIO, E.; LLAMAS, M. R. Hidrología subterránea. 2 ed. Barcelona: Omega S/A, v. 2, 1983.

EDBERG, S. C.; LECLERC, H.; ROBERTSON, J. Natural protection of spring and well drinking water against surface microbial contamination: indicators and monitoring parameters for parasites. Crit. Rev. Microbiol., v. 23, n. 2, p. 179-206, 1997.

FOSTER, S.; HIRATA, C. A. R. Determinación del risco de contaminación de aguas subterráneasuna metodología basada en datos existentes. $2 \mathrm{ed}$. Lima, Peru: CEPIS- OMS, 1991.

IBGE, Censo2000. Disponível em:<http:// www.ibge.gov.br/home/estatistica/população/ censo/2000. Acesso em: jan. 2004.

MENDONÇA, L. A. R. Modelagem matemática, química e isotópica de uma bateria de poços na cidade de Juazeiro do Norte-Ceará. $122 \mathrm{f}$. Dissertação (Mestrado em Engenharia Civil/ Recursos Hídricos) - Departamento de Engenharia Hidráulica e Ambiental, Universidade Federal do Ceará, Fortaleza. 1996.

MENDONÇA, L. A. R. et al. Isotope measurements and ground water flow modeling using MODFLOW for understanding environmental changes caused by a well field in semiarid Brazil. Environmental Geology, Springer-Verlag GmbH, v. 47, n. 8, p. $1045-1053,2005$

MINISTÉRIO DA SAÚDE. Portaria no 518 , de 2004. Normas e padróes de potabilidade da água destinada ao consumo humano. Diário Oficial da União. Brasília, DF, 2004.

SANTOS, A C. Noções de hidroquímica. In: Hidrogeologia-conceitos e aplicações. 2 ed. Fortaleza: CPRM/REFO, LABHID-UFPB, cap.5, p. 81-108. 2000
SANTOS, M. R. P. Transporte advectivo de poluentes do riacho dos Macacos ao aqüífero rio da Batateira na cidade de Juazeiro do NorteCeará. 120 f. Dissertação (Mestrado em Física) - Departamento de Física, Universidade Federal do Ceará, Fortaleza. 2003.

Endereço para correspondência:

Raimunda Moreira da Franca Departamento de Hidráulica e Ambiental

Universidade Federal do Ceará

Rua Padre Verdeixa, 850

CEP: $63100-000$ Crato - CE - Brasil

Tel.: (88) 352 I-34 I0

E-mail: rmfcariri@hotmail.com

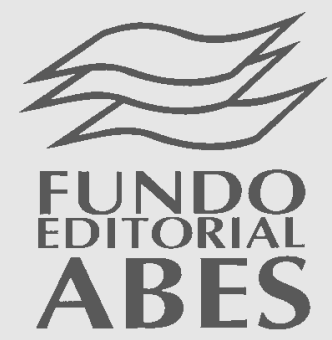

\title{
LOJA DE LIVROS ESPECIALIZADA EM SANEAMENTO E MEIO AMBIENTE
}

\author{
O Fundo Editorial dispõe de mais de 150 títulos, \\ mantendo-se sempre atualizado com pesquisas diárias \\ de novos títulos em editoras e universidades
}

Listagem organizada por assunto e tabela de preços - www.abes-dn.org.br 